\title{
Foliar diseases on tea and maté in Argentina caused by Pseudocercospora species
}

\author{
Braun $\mathbf{U}^{1}$, Rybak $\mathbf{M}^{2}$, Rybak $\mathbf{R}^{2}$ and Cabrera $\mathrm{MG}^{3}$ \\ ${ }^{1}$ Martin-Luther-Universität, Institut für Biologie, Bereich Geobotanik und Botanischer Garten, Herbarium, Neuwerk 21 \\ D-06099 Halle/S, Germany \\ ${ }^{2}$ Instituto Nacional de Tecnología Agropecuria (INTA), Estación Experimental Agropecuria, Cerro Azul, Misiones, \\ Argentina \\ ${ }^{3}$ Universidad Nacional del Nordeste, Facultad de Ciencias Agrarias, Sargento Cabral 2131, Corrientes, Argentina
}

Braun U, Rybak M, Rybak R, Cabrera MG 2012 - Foliar diseases on tea and maté in Argentina caused by Pseudocercospora species. Plant Pathology \& Quarantine 2(2), 103-110, doi $10.5943 / \mathrm{ppq} / 2 / 2 / 2$

The leaf-spotting hyphomycete Pseudocercospora theae on tea (Camellia sinensis) is described from the Province Misiones in Argentina. This is the first record of this disease from Argentina. The taxonomy of Pseudocercospora species on Camellia spp. is briefly discussed, and the species concerned are keyed out. Pseudocercospora mate is an endemic cercosporoid hyphomycete on maté (yerba mate, Ilex paraguariensis) described from Argentina. This little known species is redescribed on the base of new rich specimens recently collected in Misiones. The taxonomy of this species is discussed, above all the differentiation between $P$. mate and confused Asian collections that belong to P. naitoi. A key to Pseudocercospora species on Ilex spp. is provided.

Key words - Cercosporoid hyphomycetes - Misiones - Pseudocercospora mate Pseudocercospora theae

Article Information

Received 28 June 2012

Accepted 07 July 2012

Published online 30 July 2012

*Corresponding author: Uwe Braun - e-mail - uwe.braun@botanik.uni-halle.de

\section{Introduction}

Tea (Camellia sinensis (L.) Kuntze) and
maté (yerba mate, Paraguay tea; Ilex
paraguariensis A. St.-Hil.) are economically
important crops in the Province Misiones of
Argentina. Data on yield losses of these
cultivated plants in Argentina caused by foliar
diseases are old and scanty, and date back to
1983 in the case of maté (Rivera Flores 1983).
Therefore, a research project on foliar diseases
of these crops was carried out between 2009
and 2011 . Several causal agents of foliar
damages were identified, including cerco-
sporoid hyphomycetes which were among the
most important fungal pathogens due to the
frequency of occurrence and initiation of
premature defoliation. The leaf-spotting hypho-
mycete Pseudocercospora theae, found in
Argentina for the first time, is described, illustrated and compared with other Pseudocercospora spp. on tea. The endemic $P$. mate is the cause agent of a foliar disease on maté. Based on new collections, this little known species is re-described, illustrated, compared with allied species, and a key to the species concerned is provided.

\section{Methods}

The fungal material was examined by standard light microscopy using oil immersion (bright field and phase contrast), but without any staining. Thirty measurements $(\times 1000$ magnification) of conidia and other structures were made, with the extremes given in parentheses. 


\section{Results and discussion}

Pseudocercospora mate (Speg.) Y.L. Guo \& W.X. Zhao, Acta Mycol. Sin. 8(2): 118, 1989

Figs 1-3

$\equiv$ Cercosporina mate Speg., Anales Mus. Nac. Hist. Nat. Buenos Aires 20: 426, 1910.

$\equiv$ Cercospora mate (Speg.) Naito, Mem. Coll. Agric. Kyoto Imp. Univ. 47: 49, 1940.

$\equiv$ Cercospora mate (Speg.) Marchion., Direccion Invest. Sanid. Veg., A, 2: 7, 1946, comb. superfl.

$\equiv$ Pseudocercospora mate (Speg.) U. Braun, Schlechtendalia 5: 76, 2000, comb. superfl.

Leaf spots subcircular to somewhat angular or irregular, $1-10 \mathrm{~mm}$ diam., at first dark dingy greenish or greyish green, later pale to medium brown, greyish brown, finally grey to greyish white on the upper leaf surface and brown to greyish brown below, margin indefinite or with a narrow darker border, pale to mostly dark brown, blackish brown or purple, occasionally with a diffuse yellowish halo. Caespituli amphigenous, conspicuous on the upper side, scattered, punctiform, dark brown to blackish, less conspicuous below. Mycelium internal; hyphae branched, septate, 1-4 $\mu \mathrm{m}$ wide, subhyaline to olivaceous, smooth. Stromata almost lacking to welldeveloped, epiphyllous stromata immersed, large, 40-100(-150) $\mu \mathrm{m}$ diam., circular to irregular in outline, hypophyllous stromata almost lacking or smaller, $10-50 \mu \mathrm{m}$ diam., substomatal or occasionally intraepidermal, pale to dark olivaceous-brown, stroma cells 1.5-6 $\mu \mathrm{m}$ diam. Conidiophores in small, loose to large, dense fascicles, arising from stromata, on the upper side in large sporodochial conidiomata, erumpent, on the lower side in small to moderately large fascicles, emerging through stomata or occasionally erumpent through the cuticle, erect, straight to geniculate-sinuous, usually unbranched, occasionally with short, peg-like terminal branchlets, 5-40 × 1.5-4 $\mu \mathrm{m}, 0-1(-2)$-septate, subhyaline to pale olivaceous or olivaceousbrown, thin-walled, smooth. Conidiogenous cells integrated, terminal, or conidiophores reduced to conidiogenous cells, 5-20 $\mu \mathrm{m}$ long; conidiogenous loci (scars) inconspicuous, sometimes denticle-like, neither thickened nor darkened. Conidia solitary, narrowly obclavate-subcylindrical, long conidia sometimes subacicular-filiform, short conidia occasionally cylindrical, $(12-) 20-100 \times 1.5-4$ $\mu \mathrm{m}$, indistinctly 1-8-septate, hyaline, subhyaline or with a pale greenish or very pale olivaceous tinge, thin-walled, smooth, attenuated towards a subacute apex or tip subobtuse, base short to long obconically truncate, hilum neither thickened nor darkened, $1-1.5(-2) \mu \mathrm{m}$ wide.
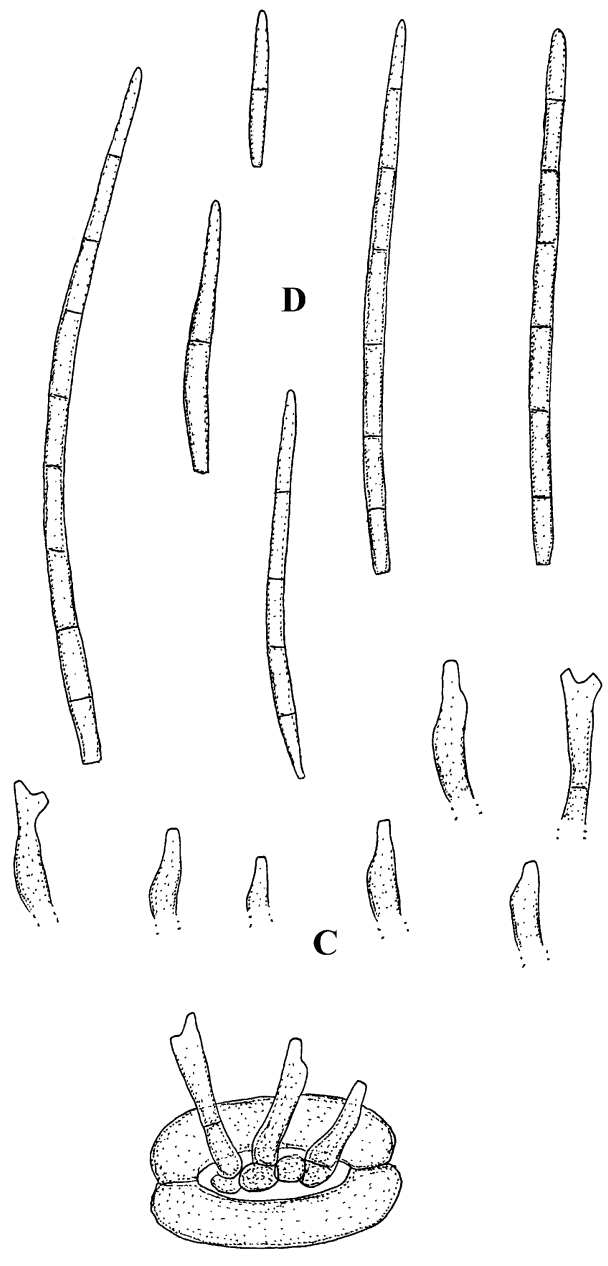

B

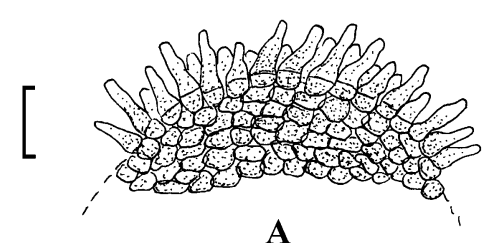

A

Fig. 1 - Pseudocercospora mate on Ilex paraguariensis, based on HAL 2504 F. A Sporodochial fascicle of conidiophores. B Small fascicle of conidiophores emerging through a stoma. C Conidiophores. D Conidia. Bar: 10 $\mu \mathrm{m}$. U. Braun del. 
Material examined - Argentina, Misiones, Santa Anna, on leaves of Ilex paraguariensis, 20 June 1909, B. Zamboni (LPS, lectotype, designated by Braun 2000); Misiones, San Ignacio, on I. paraguariensis, August 1908, J. Torre (LPS, syntype, exhausted); Misiones, Aristóbulo del Valle, 17 Mar. 2011, M. Rybak (CTES 0566507, HAL $2504 \mathrm{~F})$.

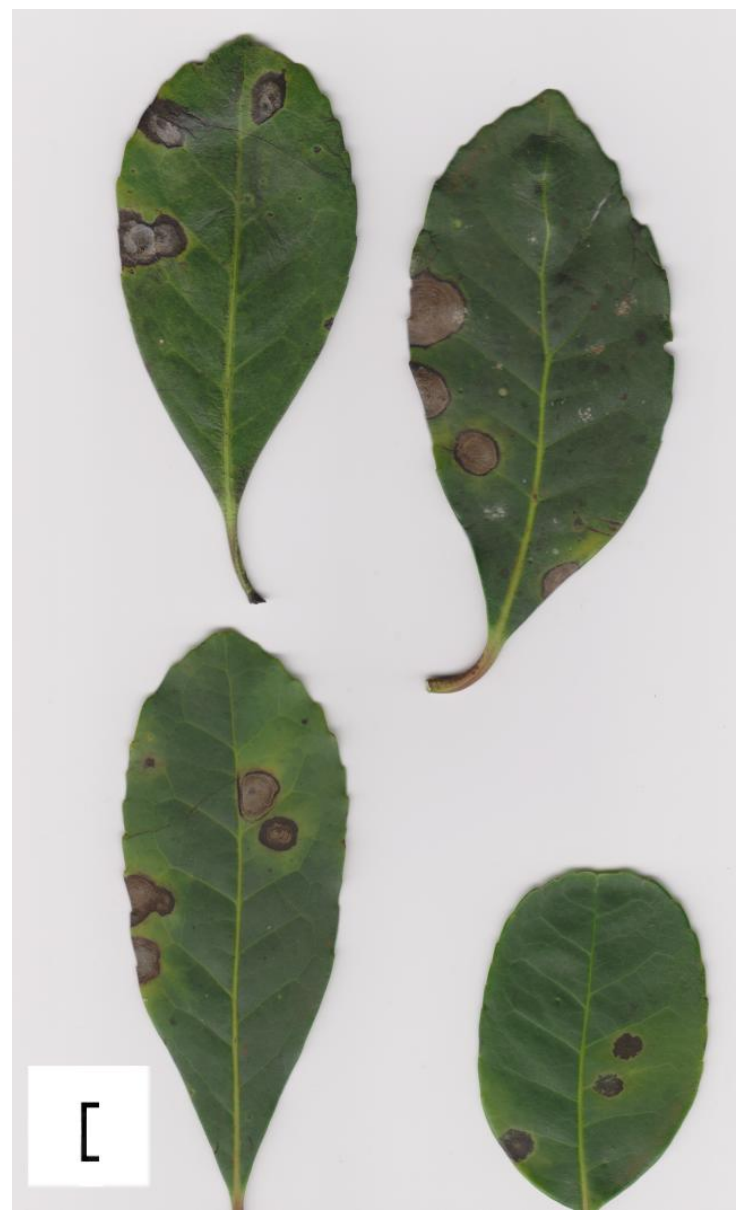

Fig. 2 - Pseudocercospora mate on Ilex paraguariensis, based on fresh material. Epiphyllous leaf spots. Bar: $1 \mathrm{~cm}$.

Cercosporina mate, described by Spegazzini (1910), was re-described by Chupp (1954) as Cercospora mate. Sutton \& Pons (1980) examined syntype material of this species collected by J. Torre at San Ignacio, but without any conclusion about its generic affinity and taxonomy as this collection is devoid of any fructification, which was also confirmed by Braun (2000) who examined type collections of this species as well. However, the latter author found fungal colonies of $C$. mate in a second syntype collection that he designated as lectotype. Based on inconspicuous conidiogenous loci in the lectotype material, he concluded that this species has to be reallocated to Pseudocercospora, but meanwhile Guo \& Zhao (1989) had introduced the new combination Pseudocercospora mate just based on Chinese collections, i.e. without comparing the Chinese samples with type material.

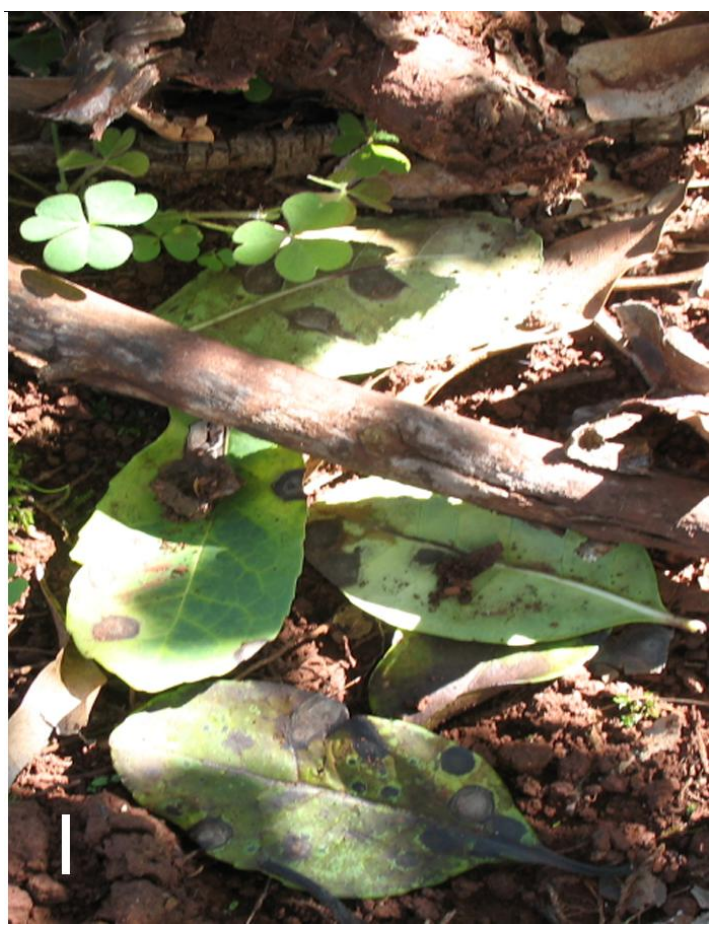

Fig. 3 - Pseudocercospora mate on Ilex paraguariensis. Lesions on leaves in a plantation after premature fall. Bar: $1 \mathrm{~cm}$.

Braun (2003) compared Japanese collections of Pseudocercospora naitoi (Nakashina et al. 1999) on Ilex chinensis Sims (=I. oldhamii Miq.) [CUP 40367] and I. serrata Thunb. [CUP 40747] with P. mate and found obvious morphological differences. He concluded that Chinese collections on Ilex spp., misidentified as $P$. mate by Guo \& Zhao (1989), Guo \& Hsieh (1995) and Guo et al. (1998), belong to $P$. naitoi as well. The latter species is distinguished from $P$. mate, which is confined to Ilex paraguariensis in South America, by its olivaceous conidia, much smaller stromata and the formation of superficial hyphae with solitary conidiophores which are present in Chinese as well as Japanese collections, although not described in Nakashina et al. (1999). The Asian Pseudo- 
cercospora species on Ilex spp. is characterized as follows

Pseudocercospora naitoi (Togashi) C. Nakash. \& Tak. Kobay., Mycoscience 40: 272, 1999

Fig. 4

$\equiv$ Cercospora naitoi Togashi, Trans. Sapporo Nat. Hist. Soc. 17: 101, 1942.

Pseudonym: "Cercospora mate Speg." sensu Naito, Mem. Coll. Agric. Kyoto Imp. Univ. 47: 49, 1940, non Spegazzini 1910.
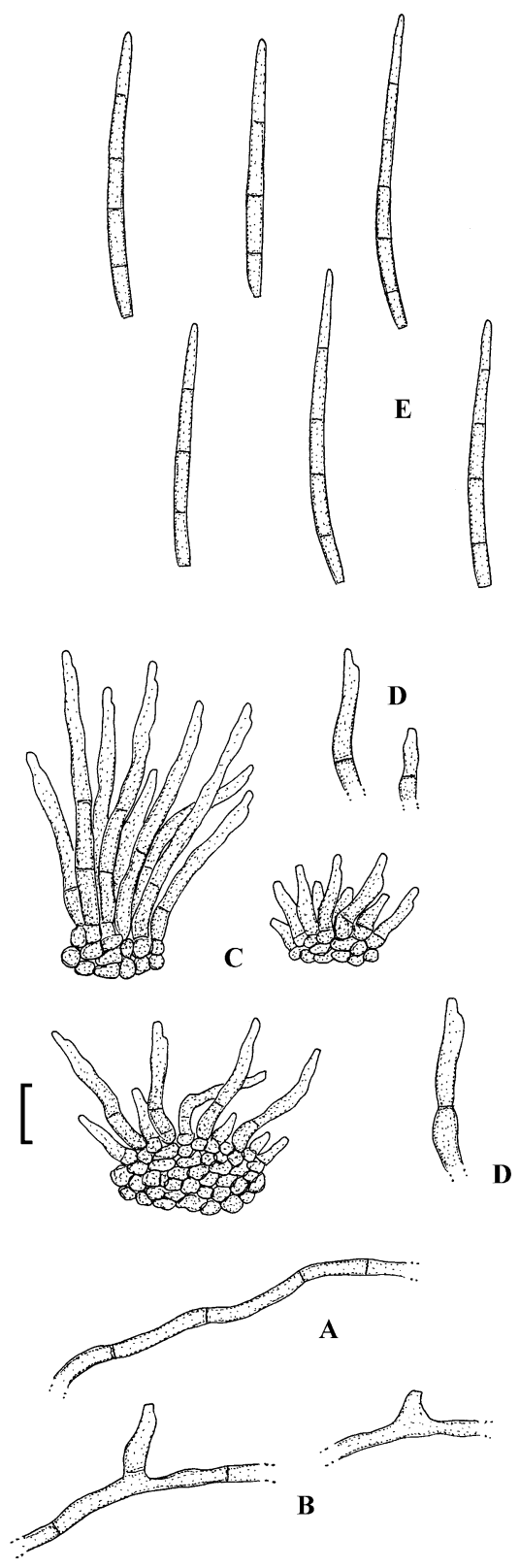

Fig. 4 - Pseudocercospora naitoi on Ilex chinensis (= I. oldhamii), based on CUP 40367. A Superficial hypha. B Superficial hyphae with solitary conidiophores. C Fascicles of conidiophores. D Conidiophores. E Conidia. Bar: $10 \mu \mathrm{m}$. U. Braun del.
Leaf spots amphigenous, subcircular to angular-irregular, sometimes confluent, 1-15 mm diam., reddish brown to blackish on the upper surface, greyish brown or grey below, margin indefinite or with a pale yellowish brown halo, sometimes spots greyish white with dark border. Caespituli amphigenous, punctiform, scattered, dark. Mycelium internal and partly also external, superficial; hyphae branched, 1.5-3 $\mu \mathrm{m}$ wide, septate, subhyaline to pale olivaceous or olivaceous-brown, thinwalled, smooth. Stromata immersed or substomatal, 10-50 $\mu \mathrm{m}$ diam., olivaceous-brown, cells 1.5-4 $\mu \mathrm{m}$ diam. Conidiophores in small to moderately large fascicles, loose to rather dense, arising from stromata, emerging through stomata or erumpent, or solitary, arising from superficial hyphae, erect, straight, subcylindrical-filiform to moderately geniculate or sinuous, usually unbranched, length variable, sometimes uniformly short, sometimes short and long conidiophores mixed, 5-50(-65) $\times$ (1.5-)2-4(-5) $\mu \mathrm{m}, 0-3$-septate, pale olivaceous or olivaceous-brown, darker in mass, thinwalled, smooth; conidiogenous cells integrated, terminal or conidiophores reduced to conidiogenous cells, 5-30 $\mu \mathrm{m}$ long, conidiogenous loci inconspicuous. Conidia solitary, obclavate to obclavate-cylindrical, (20-)30$85(-100) \times(1.5-) 2-3.5(-5) \mu \mathrm{m}, 3-11$-septate, pale olivaceous, thin-walled, smooth, apex subacute, base truncate to short obconically truncate, 1-2 $\mu \mathrm{m}$ wide, hilum unthickened, not darkened.

Naito (1940) cited Japanese collections as "Cercospora mate Speg." (he did not intend to introduce a new combination based on Cercosporina mate, but in fact did so by accident).

There are some additional species of Pseudocercospora on Ilex, viz. the North American P. ilicis (Ellis) U. Braun (Chupp 1954: 53, Braun 2003: 85 and 95, Fig. 9), $P$. ilicis-micrococcae Goh \& W.H. Hsieh (Hsieh \& Goh 1990: 26 and 28, Fig. 14) endemic in Taiwan on Ilex maximowicziana Loes. and I. micrococca Maxim., the North American $P$. pulvinula (Cooke \& Ellis) U. Braun (Chupp 1954: 54, Braun 2003: 86 and 95, Fig. 10), and the South American P. yerbae (Speg.) U. Braun (Chupp 1954: 55, Braun 2000: 74 and 75, Fig. 19). The following key contains all 
Pseudocercospora species known to be leafspotting pathogens on Ilex spp.:

\section{Key to the species of Pseudocercospora on Ilex spp.}

1. Caespituli very conspicuous, punctiform, dark brown to blackish, sporodochial, stromata well-developed, very large, 30-200 $\mu \mathrm{m}$ diam., either very large on the upper leaf side and smaller below or large and welldeveloped on the lower side; on Ilex spp. in North and South America 2

$1 *$ Caespituli less conspicuous, stromata either lacking or smaller, 10-50 $\mu \mathrm{m}$ diam.; on Ilex spp. in Asia, Europe or North America .... 4

2. On the upper leaf side with large pustulate sporodochial conidiomata, stromata very large, conidiophores very numerous, densely aggregated, on the lower side stromata lacking or small, conidiophores in smaller, looser fascicles or solitary, arising from superficial hyphae; on Ilex spp. in North America P. pulvinula

$2 *$ Mycelium internal, superficial hyphae with solitary conidiophores lacking; on Ilex spp. in South America 3

3. Epiphyllous caespituli very conspicuous, stromata immersed, large, 40-100(-150) $\mu \mathrm{m}$ diam., hypophyllous caespituli less conspicuous, stromata lacking or smaller, 10-50 $\mu \mathrm{m}$ diam., substomatal to intraepidermal; conidia (12-)20-100 × 1.5-4 $\mu \mathrm{m}$, hyaline or subhyaline; on Ilex paraguariensis, South America (Argentina) P. mate

$3^{*}$ Caespituli only hypophyllous, conspicuous, stromata always large, 75-200 $\mu \mathrm{m}$ diam.; conidia wider, 15-60 × 4-6 $\mu \mathrm{m}$, pale olivaceous; on Ilex spp., South America (Argentina) P. yerbae

4. Conidiophores long and often branched, 45$155 \mu \mathrm{m}$; on Ilex spp., Asia (Taiwan)

\section{P. ilicis-micrococcae}

4* Conidiophores much shorter and/or unbranched 5

5. Conidiophores short, 5-50(-65) $\times(1.5-) 2-$ 4(-5) $\mu \mathrm{m}$, thin-walled; conidia (1.5-)2$3.5(-5) \mu \mathrm{m}$ wide, hila $0.75-1.5 \mu \mathrm{m}$ wide; superficial hyphae with solitary conidiophores present; on Ilex spp., Asia (China, Japan) P. naitoi
$5^{*}$ Conidiophores longer and wider, (20-)30 $90(-125) \times 4-6 \mu \mathrm{m}$, wall somewhat thickened; conidia somewhat wider, 2-5 $\mu \mathrm{m}$, hila (1.5-)2(-2.5) $\mu \mathrm{m}$ wide; superficial hyphae and solitary conidiophores lacking; on Ilex spp., North America P. ilicis

Pseudocercospora theae (Cavara) Deighton, Trans. Brit. Mycol. Soc. 88: 390, 1987 Fig. 5 ESeptoria theae Cavara, Rev. Mycol. 11(44): 190, 1889.

三 Cercoseptoria theae (Cavara) Curzi, Boll. Staz. Patol. Veg. Roma, Ser. 2, 9: 385, 1929.

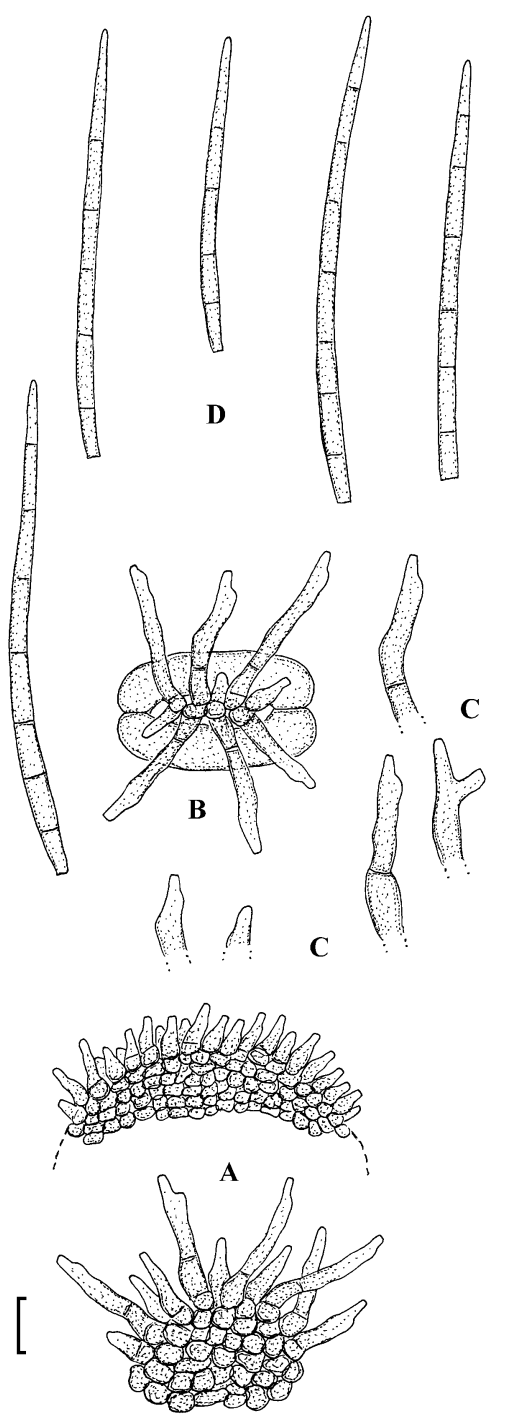

Fig. 5 - Pseudocercospora theae on Camellia sinensis, based on HAL 2505 F. A Sporodochial fascicles of conidiophores. B Small fascicle of conidiophores emerging through a stoma. C Conidiophores. D Conidia. Bar: $10 \mu \mathrm{m}$. U. Braun del. 


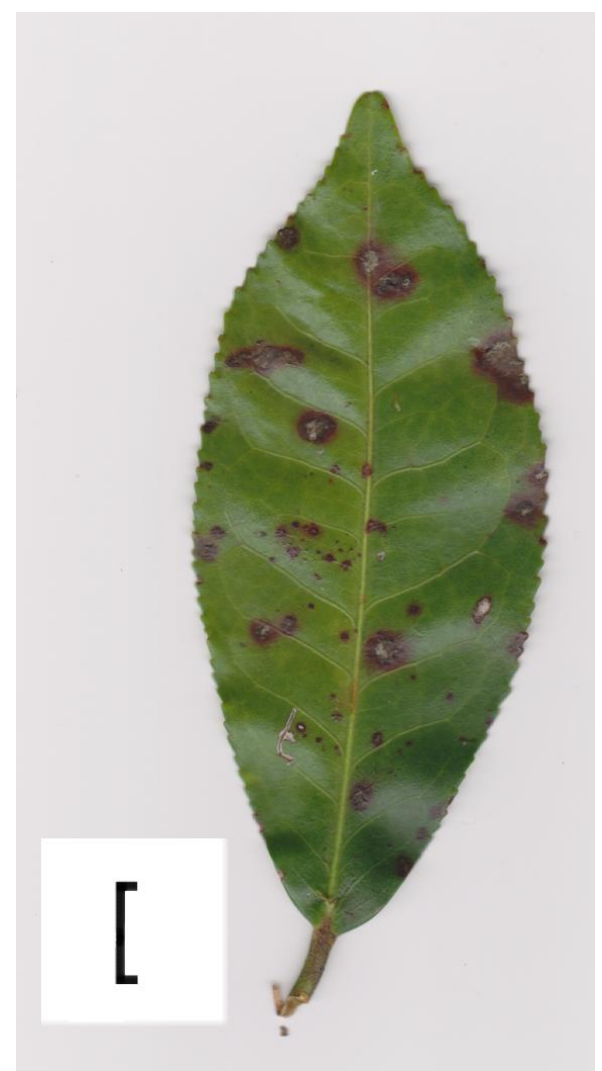

Fig. 6 - Pseudocercospora theae on Camellia sinensis, based on fresh material. Epiphyllous leaf spots. Bar: $1 \mathrm{~cm}$.

Leaf spots amphigenous, circular to somewhat angular-irregular, $0.5-3 \mathrm{~mm}$ diam., ochraceous, pale to medium dark brown, later centre becoming greyish brown, grey to greyish white, with narrow raised rim followed by a dark marginal line or halo. Caespituli amphigenous, punctiform, scattered, greyish brown to blackish. Mycelium internal, hyphae 1-2.5 $\mu \mathrm{m}$ wide, hyaline to pale olivaceous. Stromata lacking to well-developed, 10-60 $\mu \mathrm{m}$ diam., substomatal or intraepidermal (on the upper leaf side immersed, larger and welldeveloped, substomatal; lacking or smaller below). Conidiophores in small, loose to rich and dense fascicles (large fascicles with large stromata sporodochial), arising from internal hyphae or stromata, erumpent or emerging through stomata, erect, subcylindrical to strongly geniculate-sinuous, unbranched, rarely with short terminal branchlets, 5-40 × 1.5-4 $\mu \mathrm{m}, 0$-2-septate, pale olivaceous, thin-walled, smooth; conidiogenous cells integrated, terminal or conidiophores reduced to conidiogenous cells, 5-25 $\mu \mathrm{m}$ long; conidiogenous loci inconspicuous, neither thickened nor darkened.
Conidia solitary, acicular, i.e. with truncate base and gradually attenuated towards a subacute tip, to narrowly obclavate, i.e. base obconically truncate and apex obtuse to subacute, short conidia occasionally subcylindrical, 30-90 × 1.5-4 $\mu \mathrm{m}, \quad(1-) 3-9-$ septate, hyaline, subhyaline to very pale olivaceous, thin-walled, smooth, 1.5-2(-2.5) $\mu \mathrm{m}$ wide at the truncate base, hila unthickened, not darkened.

Material examined - Argentina, Misiones, Aristóbulo del Valle, on Camellia sinensis, 17 Mar. 2011, M. Rybak (CTES 0566508, HAL 2505 F)

This is the first record of Pseudocercospora theae from Argentina. This species is also known from Africa (Malawi, Mauritius and Tanzania), Asia (Hong Kong, Java, Nepal and Taiwan) and Europe (Italy). Deighton (1983) briefly described and discussed this species under the name Cercoseptoria theae, mainly based on Cavara's original description, and reallocated it later to Pseudocercospora (Deighton 1987). Hsieh \& Goh (1990: 327 and 328, Fig. 248) described and illustrated material of $P$. theae from Taiwan. $P$. theae is morphologically close to and confusable with $P$. ocellata. Several additional cercosporoid hyphomycete species are known as pathogens of Camellia spp. and have often been confused:

Pseudocercospora camelliae (Deighton) U. Braun (Braun 1993: 282)

$\equiv$ Mycocentrospora camelliae Deighton (Deighton 1983: 6).

On Camellia spp. (ornamental species), North America (USA, Georgia), New Zealand.

Pseudocercospora camelliicola U. Braun \& C.F. Hill (Braun \& Hill 2002: 222)

三Stigmina theae Deighton (1983: 4), non Pseudocercospora theae (Cavara) Deighton, 1987.

$\equiv$ Cercostigmina theae (Deighton) U. Braun (Braun 1993: 108).

On Camellia cf. japonica L., $C$. sinensis, Camellia sp. (ornamental species), Africa (Malawi and Mauritius), Asia (Nepal and Taiwan), New Zealand [Deighton (1983), Braun \& Hill (2002), Kirschner et al. (2009)]. Described in detail and illustrated from Taiwan by Kirschner et al. (2009). 
Pseudocercospora javanica Deighton (Deighton 1983: 5).

On Camellia sinensis var. assamica (J.W. Mast.) Kitam., Asia (Java).

Pseudocercospora ocellata (Deighton) Deighton (Deighton 1987: 390)

$\equiv$ Cercoseptoria ocellata Deighton (Deighton 1983: 2).

$\equiv$ Cercospora theae Breda de Haan (Breda de Haan 1900: 11), non Pseudocercospora theae (Cavara) Deighton, 1987.

On Camellia sinensis, Africa (Nigeria and Tanzania), Asia (India, Indonesia, Japan and Sri Lanka) [Crous \& Braun (2003)]. Recorded from India by Kamal (2010) and from Japan by Kobayashi (2007).

\section{Key to the species of Pseudocercospora on Camellia spp.}

1. Stromata lacking or small; mycelium internal and external; conidiophores in small fascicles, emerging through stromata, and solitary, arising from superficial hyphae; conidia acicular, 90-150 × 3-4 $\mu \mathrm{m}$; on Camellia spp. in North America and New Zealand P. camelliae

$1 *$ Stromata well-developed; superficial mycelium and solitary conidiophores lacking .. 2

2. Conidiomata sporodochial, composed of large immersed stromata, 50-120 $\mu \mathrm{m}$ diam., and numerous densely arranged conidiophores (stromata sometimes becoming spermogonia or pycnidia with a single locule); conidiogenous cells unilocal, determinate or percurrently proliferating, annellations not very conspicuous; conidia \pm acicular, 50$170(-190) \times 2.5-4 \mu \mathrm{m}$; on Camellia spp. in Africa, Asia and New Zealand

P. camelliicola

2* Stromata smaller, < $60 \mu \mathrm{m}$; conidiogenous cells with a single to several loci, proliferation sympodial; conidia somewhat shorter, about $30-125 \mu \mathrm{m}$ 3

3. Conidiophores relatively short, 5-40 × 1.5-4 $\mu \mathrm{m}, \quad 0$-2-septate, unbranched; conidia acicular to narrowly obclavate, base truncate to distinctly obconically truncate; on Camellia spp., Africa, Asia, Europe, South America P. theae

3* Conidiophores longer, $25-85 \mu \mathrm{m}$, up to 5septate, occasionally branched; conidial base uniformly truncate or short obconically truncate 4

4. Leaf spots small, up to about $2 \mathrm{~mm}$ diam., evident as typical eye-spots (at first black or purplish, later with pale center surrounded by a narrow swollen purplish brown margin); conidia acicular-filiform, base truncate, about $50-80 \times 2-4 \mu \mathrm{m}$; on Camellia sinensis, Africa and Asia

P. ocellata

4* Leaf spots greyish brown, size and shape variable, up to $20 \mathrm{~mm}$ diam., margin indefinite; conidia narrowly obclavatefiliform, base short obconically truncate, longer, about 70-125 × 2.5-3 $\mu \mathrm{m}$; on Camellia sinensis, only known from Java P. javanica

\section{References}

Braun U. 1993 - New genera of phytopathogenic Deuteromycetes. Cryptogamic Botany 4, 107-114.

Braun U. 2000 - Annotated list of Cercospora spp. described by C. Spegazzini. Schlechtendalia 5, 57-79.

Braun U. 2003 - Miscellaneous notes on some cercosporoid hyphomycetes. Bibliotheca Lichenologica 86, 79-98.

Braun U, Hill CF. 2002 - Some new micromycetes from New Zealand. Mycological Progress 1, 19-30.

Breda de Haan J van 1900 - Vorläufige Beschreibung von Pilzen, bei tropischen Kulturpflanzen beobachtet. Bulletin de l'Institut Botanique de Buitenzorg 6, 1113.

Chupp C. 1954 - A monograph of the fungus genus Cercospora. Ithaca.

Crous PW, Braun U. 2003 - Mycosphaerella and its anamorphs: 1 . Names published in Cercospora and Passalora. CBS Biodiversity Series 1, 1-569.

Deighton FC. 1983 - Studies on Cercospora and allied genera. VIII. Further notes on Cercoseptoria and some new species and redispositions. Mycological Papers 151, 1-13.

Deighton FC. 1987 - New species of Pseudocercospora and Mycovellosiella, and new combinations into Pseudocercospora and Phaeoramularia. Transactions of the 
British Mycological Society 88, 365391.

Guo YL, Hsieh WH. 1995 - The genus Pseudocercospora in China. Mycosystema Monographicum Series No. 2, International Academic Publishers, Beijing.

Guo YL, Liu XJ, Hsieh WH. 1998 - Flora Fungorum Sinicorum, Vol. 9. Pseudocercospora. Science Press, Beijing.

Guo YL, Zhao WX. 1989 - Studies on Hyphomycetes of Zhangjiajie in Hunan. I. Pseudocercospora. Acta Mycologica Sinica 8, 118-122.

Hsieh WH, Goh TK. 1990 - Cercospora and similar fungi from Taiwan. Maw Chang, Taipei, Taiwan.

Kamal. 1910 - Cercosporoid Fungi of India. Bishen Singh Mahendra Pal Singh, Dehra Dun.

Kirschner R, Hou C-L, Chen C-J. 2009 - Cooccurrence of Pseudocercospora species and rhytismatalean ascomycetes on maple and camellia in Taiwan. Mycological Progress 8, 1-8.
Kobayashi T. 2007 - Index of fungi inhabiting woody plants in Japan. Host, distribution and literature. Zenkoku-Noson-Kyokai Publishing, Japan.

Naito N. 1940 - Notes on some new or noteworthy fungi of Japan. Memoirs of the College of Agriculture, Kyoto Imperial College 47, 45-52.

Nakashima C, Nishijima T, Kobayashi T. 1999 - Addition and reexamination of Japanese species belonging to the genus Cercospora and allied genera II. Species described by Japanese mycologists (1). Mycoscience 40, 269-276.

Rivera Flores SE. 1983 - Identificación de enfermedades de la yerba mate. Estación Experimental Agropecuria, Cerro Azul, Misiones, Argentina, Miscelánea 7, 1-38.

Spegazzini C. 1910 - Mycetes Argentinenses, Ser. V. Anales del Museo Nacional de Historia Natural de Buenos Aires 20, 329-467.

Sutton BC, Pons N. 1980 - Notes on the original species of Cercosporina. Mycotaxon 12, 201-218. 